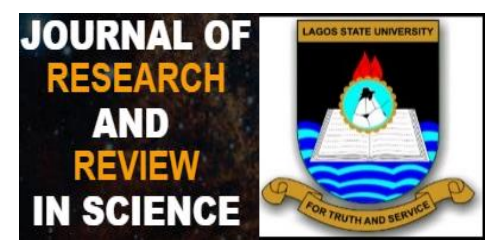

\title{
Stimulating Diffusion of Bio-based Products: The Role of Responsible Research and Innovation (RRI) Approach
}

\section{Oluwaseun J. Oguntuase ${ }^{1}$, Oluwastosin B. Adu' ${ }^{2}$, Oluwafemi S. Obayori ${ }^{3}$}

${ }^{1}$ Centre for Environmental Studies and Sustainable Development (CESSED), Lagos State University, Nigeria

${ }^{2}$ Department of Biochemistry,

Faculty of Science, Lagos State University, Nigeria

${ }^{3}$ Department of Microbiology,

Faculty of Science, University of Lagos, Nigeria

\section{Correspondence}

Oluwaseun J. Oguntuase, Centre for Environmental Studies and Sustainable Development (CESSED), Lagos State University, Nigeria.

Email:oluwaseunoguntuase@gmail.com

\begin{abstract}
:
Introduction: Escalating environmental challenges have necessitated the adoption of bio-based products. The social interface between these products with low environmental impacts and the society is a dynamic site where different stakeholders, forms of knowledge, interests and powers interplay. Scientists must navigate these factors for bio-based products to become acceptable in the society.

Aims: This review explores the suitability of responsible research and innovation (RRI) as an inclusive approach to research and innovation to support the adoption and diffusion of bio-based products in the society.

Method: The study was essentially based on a desk review of relevant academic papers on bio-based products, bio-based economy, bioeconomy and, responsible research and innovation (RRI) from year 2012 - 2018, with reference to other publicly accessible documents and publications.

Results: The review shows that despite their potentials for contributing to greener environment and sustainability, bio-based products remain controversial. Results also show that embedding RRI dimensions in development of bio-based products "from lab to market" will help build trust among stakeholders in the relevant value chain, which is a prerequisite for the diffusion of these products in the society.

Conclusion: The main conclusion of this paper is that identifying and engaging stakeholders, the publics and their concerns when developing bio-based products will ensure the products are relatively uncontested and will diffuse better throughout the society.
\end{abstract}

Keywords: bio-based product, bio-based economy, bioeconomy, responsible research and innovation 


\section{INTRODUCTION}

Increasing depletion of earth's finite resources, climate change and environmental concerns, cutting-edge biotechnological advancements, economic considerations, changing demographics and quest for sustainable development have converged to project bio-based economy or bioeconomy (henceforth, biobased economy) as a more sustainable alternative way to live. The concept of bio-based economy has continued to gain traction both in science and policy. It is the production of renewable biological resources and the conversion of these resources, residues, byproducts and side streams into value added products such as food, feed, bioenergy and other bio-based products [1]. Adoption and diffusion of these bio-based products in the society is crucial for sustainable biobased economy.

According to the European Standard (EN 16575:2014), bio-based products are wholly or partly derived from materials of biological origin, excluding materials embedded in geological formations and/or fossilized. Bio-based products are categorized into products originating directly from biomass, products made from building blocks originating from biomass, and products produced by microorganisms [2].

Responsible Research and Innovation (RRI) has been increasingly used among policy makers and academics to ensure science and scientists proceed in socially responsible ways [3]. The assumption behind $\mathrm{RRI}$ is that if innovations are developed with participation of multiple stakeholders in the research and development process, an eye for social and ethical concerns, and with the objective of better aligning the outcomes of the values, needs and expectations of society, they will be (relatively) uncontested and will therefore diffuse better throughout society [4]. RRI is an approach that includes relevant stakeholders "from lab to market", anticipating potential implications, reflecting and responding to the needs and values of society [5]. Focusing on these stakeholders is of paramount importance for deepening our knowledge of the main social aspects that may influence the diffusion of biobased products, which is currently still limited.

The rest of the paper is organized as follows: Section 2 frames the context of analysis and presents the research questions. Section 3 describes the methodology. Section 4 presents categories of biobased products, relevant studies starting from the controversial nature of bio-based products, and RRI in the context of bio-based products. Section 5 contains a discussion of the results. Finally, Section 6 concludes and states the contributions of the study to literature.

\section{THE CONTEXT OF ANALYSIS AND RESEARCH QUESTIONS}

An innovation is defined as "an idea, practice, or object that is perceived as new by an individual or other unit of adoption" [6]. The definition shows that an innovation can take various forms or appearances. It may be a tangible product but may also be intangible - a service or a behavioral pattern. A product is only an innovation if it is perceived as new. Bio-based products meet these criteria; they are tangible and relatively new phenomena. In addition to these two criteria, they are a departure from current/existing products, therefore also meeting the 'radicalness' or 'discontinuity' criterion of innovation.

The conception of this study is that bio-based products are wholly or partly derived from materials of biological origins, such as plants, trees or animals, the biomass may have undergone physical, chemical or biological treatment, but excludes materials embedded in geological formations and/or fossilized. Also excluded are traditional bio-based products, such as pulp and paper, and wood products, and bio-mass as an energy source.

Diffusion is "the process by which an innovation is communicated through certain channels over time among the members of a social system"[7]. Accordingly, the success of an innovation depends crucially on the social system. Diffusion theory focuses on how quickly and to what degree a social system accepts an innovation. Although adoption and diffusion are two different processes, they are highly interrelated. Adoption decisions drive every diffusion process. The major difference between adoption and diffusion is the aggregation level at which the processes are studied: adoption theory is concerned with adoption decisions of individual units (at a disaggregate level), whereas diffusion theory is concerned with dissemination on an aggregate level [8]. Li and Jin noted that the essence of a new product's diffusion process is the product information exchanged by which one individual communicates a new product to one or several others [9].

This paper adopts Stahl's working definition of responsible research and innovation $(R R I)$ as a higher level responsibility or meta-responsibility that aims to shape, maintain, develop, coordinate and align existing and novel research and innovation-related processes, actors and responsibilities with a view to ensuring desirable and acceptable research outcomes [10]. This definition is consistent with established views that RRI should incorporate social concerns and democratic accountability into research and innovation to ensure mutual responsiveness of stakeholders and establish principles of anticipatory governance of research and innovation.

While the phenomena of individual adoption of a new product and its diffusion through a population have received much attention, research within the diffusion paradigm that explicitly considers the importance of the RRI approach in diffusion of bio-based products is very limited. In applying diffusion theory, we seek to establish how RRI approach will help bio-based products get accepted within in the society. 
Accordingly, this paper will seek to answer the following research questions:

$R Q 1:$ Is the RRI approach ideal for engaging relevant stakeholders to ensure diffusion of bio-based products?

RQ2: How are RRI dimensions applicable to relevant stakeholders in bio-based products?

\section{METHODOLOGY}

The scope of our analysis ranges from scientific journals and official published documents (e.g., conference proceedings and books) to the so-called "grey literature" (reports). The publication date covered was 2012 -2018.

Following Fink [11] and Pfau,Hagens, Dankbaar \& Smits [12] there was selection of key search terms bio-based products, bio-based economy, bioeconomy and, responsible research and innovation (RRI), followed by application of screening criteria to identify relevant literature using Google Scholar search engine and other academic communities - Academia, ResearchGate and the Social Science Research Network (SSRN). The relevant papers were reviewed and the findings collated.

\section{RESULTS}

\subsection{Bio-based Products}

While much of the focus on the bio-based economy has been on biobased fuels and energy sources [13], there are several other bio-based products. These include manufactured goods such as biobased chemicals, bioplastics, biopolymers, biocomposites, alcoholic and non-alcoholic beverages, fermented foods, food additives and ingredients, feed, and specialties such as biosurfactants, lubricants, and pharmaceuticals and neutraceutics.

Figure 1. Bio-based products in the emerging bio-based economy

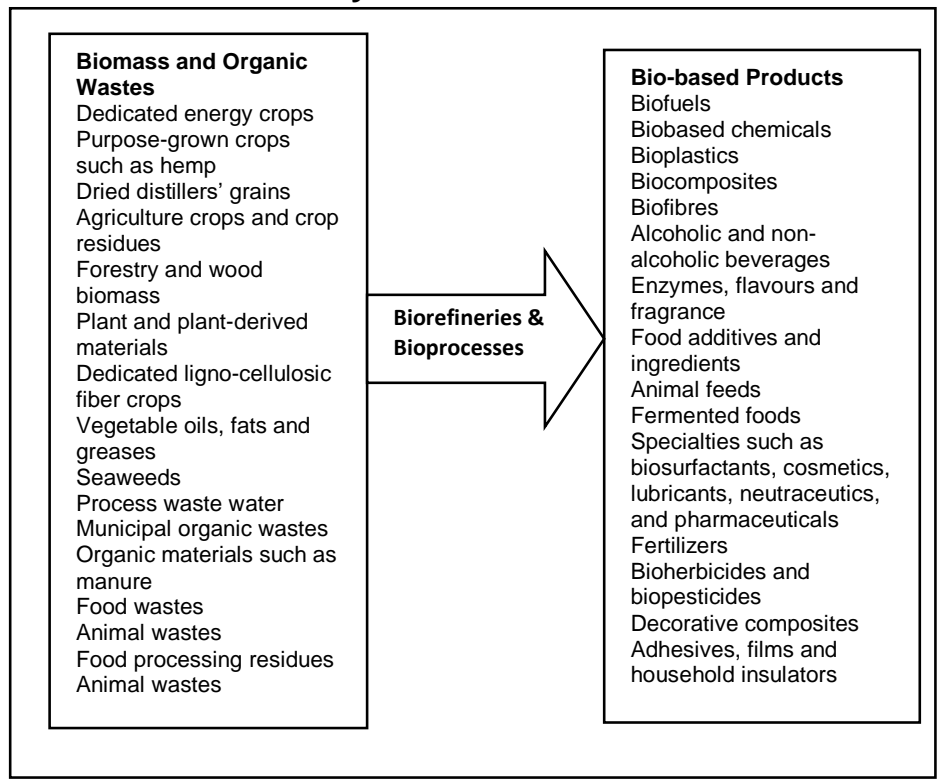

\subsection{Relevant Stakeholders in Bio-based Products Innovation and Diffusion}

Diffusion of the bio-based products depends on the engagement of a range of stakeholders and publics. Publics represents groups who lack the direct connection to bio-based product innovation that stakeholders have and also differ from stakeholder groups in terms of their level of organization and visibility, but nonetheless have interests, concerns, hopes, fears, and values that can contribute to democratic decision making $[14,15,16]$.

Stakeholders involved in bio-based products innovation and diffusion are individual researchers, research organizations (both publicly and privately funded), research ethics committees and their members, funding agencies, policy makers at different levels, farmers, fishermen, agribusinesses, food processors, waste handlers, manufacturers, civil societies and nongovernmental organizations, business associations, professional bodies, legislators, educational organizations (e.g. schools and universities) and public bodies (from local authorities to regional structures) $[10,17,18]$.

\subsection{Bio-based Products are Emerging and Controversial}

Our literature review shows that the concept of biobased economy and bio-based products is still emerging [19,20,21], controversial [22,23,24,25,26,27] and conceived rather differently from various stakeholder perspectives [28,29].

The diverse perspectives on bio-based products include appropriate sustainability criteria, food vs biofuel debate, arguments for and against GMOs, and the ethics of innovation. The vision upon which national bio-economy policy is based will also dictate the legal frameworks of the bio-based products. Bugge et al. listed three visions of bio-based economy to include the bio-technology vision, the bio-resource vision, and the bio-ecology vision [28].

\subsection{RRI in the Context of Novel Bio-based Products}

Elster called for the promotion of responsible research and innovation (RRI) in respect to biosciences research to create a shared understanding of the appropriate roles of those who have a stake in the processes and products of science and technology, scientists, as well as educators and the general public [30]. This opinion was supported by $\mathrm{Yu}$ that RRI will help realize public benefit objective and obtain the optimal social and economic values from biomedical research [31]. This is more important in bio-based economy which requires changes in the social structures embedding the bio-economy. RRI will help to handle socially sensitive issues involved that need to be addressed to prevent social resistance [24]. 
Asveld, Ganzevles, \& Osseweijer proposed a responsible research and innovation (RRI) approach to stimulate the development and diffusion of bio-based products [32]. The authors believed that for the further development and diffusion of the bio-based products, trust among actors in the relevant value-chain is a prerequisite and that RRI can play a pivotal part in the bio-based economy by providing conditions for trustworthiness of actors and by enhancing trusting relationships. van Lancker, Wauters, \& van Huylenbroeck had earlier submitted that the inherent characteristics of RRI make it an appropriate framework to stimulate the development and diffusion of bio-based products [33].

\subsection{Applying RRI Dimensions to Bio-based Products Diffusion}

Table 1 enumerates how RRI could be used to incorporate the concerns of a broad array of actors into bio-based products research and development to ensure their diffusion in the society.

\section{Table 1. Dimensions of RRI}

\begin{tabular}{|c|c|c|}
\hline Dimension & $\begin{array}{l}\text { Relevance to bio-based products } \\
\text { diffusion }\end{array}$ & $\begin{array}{l}\text { Selected relevant } \\
\text { stakeholders }\end{array}$ \\
\hline Anticipation & $\begin{array}{l}\text { Why should the bio-based product be } \\
\text { developed? } \\
\text { Will the bio-based product be socially } \\
\text { desirable? } \\
\text { Is the process of developing the bio-based } \\
\text { product acceptable? } \\
\text { To what extent can the future uses and } \\
\text { impacts of the bio-based product be } \\
\text { anticipated? } \\
\text { Have we included the right stakeholders? }\end{array}$ & $\begin{array}{l}\text { Individual } \\
\text { researchers } \\
\text { Research } \\
\text { organizations } \\
\text { Ethics committees } \\
\text { Policy makers } \\
\text { Education } \\
\text { institutions } \\
\text { Funding agencies }\end{array}$ \\
\hline Reflexivity & $\begin{array}{l}\text { Is the bio-based product controversial? } \\
\text { Can we develop the biobased product } \\
\text { differently? } \\
\text { Is there an alternative bio-based product? } \\
\text { What might be the potential use of the bio- } \\
\text { based product? } \\
\text { What don't we know about? } \\
\text { How can we ensure societal desirability? }\end{array}$ & $\begin{array}{l}\text { Policy makers } \\
\text { Civil societies } \\
\text { NGOs } \\
\text { Professional bodies } \\
\text { Ethics committees } \\
\text { Funding agencies }\end{array}$ \\
\hline Inclusion & $\begin{array}{l}\text { Is there a national definition of bio-based } \\
\text { products? } \\
\text { What are the viewpoints of a wide group of } \\
\text { stakeholders? } \\
\text { Is the bio-product acceptable? } \\
\text { Who determines the bio-based product(s) } \\
\text { to develop? } \\
\text { Whose priority is the bio-based product? }\end{array}$ & $\begin{array}{l}\text { Business } \\
\text { associations } \\
\text { Biomass producers } \\
\text { Agribusinesses } \\
\text { CSOs } \\
\text { NGOs }\end{array}$ \\
\hline Responsiveness & $\begin{array}{l}\text { Who matters? } \\
\text { What needs to be done to make bio-based } \\
\text { products desirable? } \\
\text { What training or enlightenment is } \\
\text { required? } \\
\text { Which networks are required? } \\
\text { How do we ensure that the implied future } \\
\text { is desirable? }\end{array}$ & $\begin{array}{l}\text { Agribusiness } \\
\text { Professional bodies } \\
\text { Biomass producers } \\
\text { Business } \\
\text { associations } \\
\text { NGOs } \\
\text { CSOs }\end{array}$ \\
\hline Sustainability & $\begin{array}{l}\text { Is the bio-based product sustainability } \\
\text { anticipated? } \\
\text { Which environmental and social problems } \\
\text { will the bio-based product solved? } \\
\text { What are the bio-based product } \\
\text { sustainability criteria? } \\
\text { How are resources conserved during the } \\
\text { bio-based product production? } \\
\text { Are the bio-based products designed to be } \\
\text { safe and ecologically sound? } \\
\text { What is the quantity of petroleum based } \\
\text { products been replaced? }\end{array}$ & $\begin{array}{l}\text { Manufactures } \\
\text { Waste handlers } \\
\text { Food processors } \\
\text { Biomass producers } \\
\text { Agribusinesses } \\
\text { Policy makers }\end{array}$ \\
\hline Economic & $\begin{array}{l}\text { What is the expected contribution to GDP, } \\
\text { employment and foreign exchange? } \\
\text { What is the expected return on } \\
\text { investment? } \\
\text { Are the investment risks covered? } \\
\text { What are the key drivers of bio-based } \\
\text { products market development? } \\
\text { Are there stable. long term and supportive } \\
\text { bioeconomy policies? } \\
\text { How do bio-based products compared in } \\
\text { price to other products? }\end{array}$ & $\begin{array}{l}\text { Investors } \\
\text { Shareholders } \\
\text { Investment bankers } \\
\text { Venture capitals }\end{array}$ \\
\hline
\end{tabular}

LASU Journal of Research and Review in Science

\section{DISCUSSION}

Our study showed availability of several RRI activities and approaches such as, scenario-building, stategates, user-centred design, deliberate polling, niche management, socio-economic impact analysis, etc., that could be employed to reflect on the vision, motivations, processes, risks, sustainability and economic benefits of bio-based products. These activities and approaches are useful for lower and higher levels engagement with relevant stakeholders, and to instruct and educate publics that do not participate in bio-based product innovation, and to tackle this mistrust of new science and can legitimize bioscience research and bioeconomy development decisions to ensure wider societal benefit.

As previously underlined and tabulated, RRI dimensions are extensively applicable to relevant stakeholders involved in bio-based products innovation and those whose opinions and contributions are vital to the products diffusion. The dimensions are also relevant in instructing and educating publics that do not participate in bio-based product innovation, and to tackle this mistrust of new science and can legitimize bioscience research and bioeconomy development decisions to ensure wider societal benefit.

It is important to remark that the RRI will help researchers and policy makers to be aware of public understanding and expectations of bio-based products in order to advance their diffusion and by extension bio-based economy as a future economic model, away from our current unsustainable fossil economic model.

\section{CONCLUSION}

In this paper we have attempted to give a short overview of the relevance of RRI approach in influencing the diffusion of bio-based products in the society. It is clear that the success of sustainable bioeconomy will depend on diffusion of bio-based products. Employing RRI approach to engage with relevant stakeholders will not ensure that bio-based products are relatively uncontested but accelerate their market-uptake, leading to better diffusion through the society to help solve several societal challenges.

Our contribution to the literature on RRI is to build the connection between its dimension and diffusion of biobased products, demonstrating how the RRI approach will accelerate market-uptake of bio-based products. The advancement of sustainable bioeconomy to solve several societal challenges required an inclusive approach; our call is for the innovation ecosystem to be built on RRI dimensions to bring all relevant stakeholders into the bio-based products innovation matrix. 


\section{REFERENCES}

1. European Commission. Innovating for sustainable development growth: a bioeconomy for Europe. Brussels, Belgium: European Commission;2012.

2. Molenveld, K, Oever, MVD, Bos, H. Biobased packaging catalogue. Wageningen, Netherlands: Wageningen UR Food \& Biobased Research; 2015.

3. Gwizdała JP, Śledzik K. Responsible research and innovation in the context of university technology transfer. Acta Universitas Lodzensis. Folia Oeconomica. 2017;2(328):55-73. doi: 10.18778/0208-6018.328.04

4. Expert Group on the State of Art of Europe. Options for strengthening responsible research and innovation. Luxembourg: European Commission;2012.

5. Thomas E, Maines L. Management of stakeholders' knowledge for responsible research and innovation. Paper presented at the Proceedings of the ISPIM Innovation Conference, Stockholm, Sweden; 2018, June.

6. Rogers EM. Diffusion of innovations. New York: The Free Press; 1995.

7. Rogers EM. Diffusion of Innovations. New York: Free Press of Glencoe; 1962.

8. Driessen PH, Hillebrand B. Adoption and diffusion of green innovations. In: Bartels GC, Nelissen WJA, editors. Marketing for Sustainability: Towards Transactional Policy-Making (pp. 34355). Amsterdam: IOS Press; 2002.

9. Li SP, Jin Z. Global dynamics analysis of homogeneous new products diffusion model. Discrete Dyn Nat Soc. 2013. doi: 10.1155/2013/158901

10. Stahl BC. Responsible research and innovation: the role of privacy in an emerging framework. Sci Public Policy.2013; 40(6):708-716. doi:10.1093/scipol/sct067

11. Fink $A$. Conducting research Literature reviews. 3rd ed. Thousand Oaks (CA), USA: SAGE Publications, Inc; 2010.

12. Pfau SF, Hagens JE, Dankbaar B, Smits AJM. (2014). Visions of sustainability in bioeconomy research. Sustainability. 2014; 6:1222-1249. doi: 10.3390/su6031222

13. Golden JS, Handfield RB. Opportunities in the emerging bioeconomy. Washington, DC: US Department of Agriculture, Office of Procurement and Property Management; 2014.

14. Gerdes H, Kiresiewa Z, Beekman V, Bianchini C, Davies S, Griestop L, et al. Engaging stakeholders and citizens in the bioeconomy: Lessons learned from BioSTEP and recommendations for future research. Berlin: Ecologic; 2018.

15. Mohr A, Raman S, Gibbs B. Which publics? When? Exploring the policy potential of involving different publics in dialogue around science and technology. Nottingham: University of Nottingham; 2013.

16. National Academies of Sciences, Engineering, and Medicine. Gene drives on the horizon: advancing science, navigating uncertainty, and aligning research with public values. Washington DC: The

LASU Journal of Research and Review in Science
National Academies Press; 2016. doi:10.17226/23405

17. Hausknost ES, Lauk C, Kalt G. A transition to which bioeconomy? An exploration of diverging techno-political choices. Sustainability. 2017; 9(4): 669. doi:10.3390/su9040669

18. Socaciu C. Bioeconomy and green economy: European strategies, action plans and impact on life quality. Bulletin Univ of Agric Sci \& Vet Med Cluj-Napoca Food Sci Tech. 2014; 71(1). doi: 10.15835/buasvmcn-fst:10121

19. Devaney LA, Henchion M, Regan A. Good governance in the bioeconomy. EuroChoices. 2017; 16(2): 41-46. doi: 10.111/1746-692x.12141

20. Giurca A, Metz T. A social network analysis of Germany's wood-based bioeconomy: social capital and shared beliefs. Environ Innov Soc Transit. 2018; 26: 1-14. doi: 10.1016/j.eist.2017.09.001

21. Imbert E, Ladu L, Morone P, Quitzow R. Policy strategies for a transition to a bioeconomy in Europe: the case of Italy and Germany. MPRA Paper. 2017; 78143. Accessed 11 September 2018. Available: https://mpra.ub.unimuenchen.de/78143/

22. de Bakker E, Ribeiro B, Millar K, Beekman V. Actors and network activities in the bioeconomy: reflections on guidelines for participatory approaches. Brussels, Belgium: European Union; 2016.

23. Bauer F. Innovation for biorefineries - networks, narratives, and new institutions for the transition to a bioeconomy. Lund, Sweden: Lund University Faculty of Engineering; 2018.

24. Duca G, Trupiano G. Bioeconomy and the challenge of community centered design. In: Ulgiati S, Vanoli L, chairs. Energy futures, environment and well-being. Biennial International Workshop Advances in Energy Studies, BIWAES 2017, Naples, Italy; 2017, September.

25. Hansen JS. The Danish biofuel debate: coupling scientific and politico-economic claims. Sci Cult. 2014; 23(1): 73-97. doi: 10.1080/09505431.2013.808619

26. Hedlund-de Witt $A$. An integral perspective on the (un)sustainability of the emerging bio-economy: using the integrative worldview framework for illuminating a polarized societal debate. Delft, Netherlands: Delft University of Technology Biotechnology and Society Section; 2013.

27. Peltomaa J, Kolehmainen J. Ten years of bioeconomy in the Finnish media. Alue ja ymäristö. 2017; 46(2): 57- 63.

28. Bugge MM, Hansen $T$, Klitkou A. What is the bioeconomy? A review of the literature. Sustainability. 2016; 8(7), (691): 1-22. doi: 10.3390/su8070691

29. Székács A. Environmental and ecological aspects in the overall assessment of bioeconomy. J Agric Environ Ethics. 2017; 30: 153. doi: 10.1007/s10806-017-9651-1

30. Elster D. Raising awareness of responsible research and innovation (RRI) in biosciences. Paper presented at the International Conference 
on New Perspective in Science Education, Florence, Italy; 2018, March.

31. $\mathrm{Yu} H$. Redefining responsible research and innovation for the advancement of biobanking and biomedical research. J Law Biosci. 2016; 1-25. doi:10.1093/jlb/lsw047

32. Asveld I, Ganzevles J, Osseweijer P. Trustworthiness and responsible research and innovation: the case of the bioeconomy. J Agric Environ Ethics. 2015; 28:571-588. doi:10.1007/s10806-015-9542-2

33. van Lancker J, Wauters E, Van Huylenbroeck G. Managing innovation in the bioeconomy: an open innovation perspective. Biomass Bioenergy. 2016; 90: 60-69.

\section{APPENDIX}

\section{Appendix 1. Bio-based co-products}

\begin{tabular}{|c|c|}
\hline Fuels & Ethanol \\
\hline $\begin{array}{l}\text { Household } \\
\text { furnishings }\end{array}$ & $\begin{array}{l}\text { Bedding and bed linens, Towels, Tableware, } \\
\text { Upholstery, Soy wax candles, Carpets and carpet } \\
\text { backing, Furniture protectors, Soy - Based foam for } \\
\text { household furniture, Computer plastics, Electronic } \\
\text { plastics, Lignin - based printed wiring boards, } \\
\text { Electronic acoustic foams, Wall coverings, Window } \\
\text { coverings, Natural furniture, Biobased polyurethane } \\
\text { refrigerator insulators, Toys, Cellulose - based } \\
\text { batteries (in development) }\end{array}$ \\
\hline $\begin{array}{l}\text { Household } \\
\text { supplies }\end{array}$ & $\begin{array}{l}\text { Laundry detergents, Bathroom tub and tile cleaners, } \\
\text { Fertilizers, Paint strippers, Hydraulic fluids, Mold and } \\
\text { mildew removers, Lubricants, Dry erase board cleaner, } \\
\text { Household cleaning solvents, Soy ink toner cartridges } \\
\text { for printers, Household paints, Stainless steel and glass } \\
\text { cleaners, Drain and septic tank cleaners, Floor } \\
\text { cleaners, Insecticides, Wood sealant and } \\
\text { waterproofing, Wood stains, Air fresheners }\end{array}$ \\
\hline Personal care & $\begin{array}{l}\text { Apparel,Textiles,Footwear,Shampoo and conditioners, } \\
\text { Lip balms, Cosmetics, Soap bars, Pet shampoo, } \\
\text { Deodorants, Sun care products, Shaving products, } \\
\text { Lotions, Moisturizers, Hand cleaners, Razors }\end{array}$ \\
\hline $\begin{array}{l}\text { Automotive } \\
\text { sector }\end{array}$ & $\begin{array}{l}\text { Car tires, Soy - based foam for automotive seats, } \\
\text { Acoustical products, Structural foam, Seat cushions, } \\
\text { Sunshades, Headrests, Headliners, Armrests, } \\
\text { Elastomers }\end{array}$ \\
\hline $\begin{array}{l}\text { Construction } \\
\text { sector }\end{array}$ & $\begin{array}{l}\text { Acoustic panels, Structural wall panels, Plastic } \\
\text { lumber, Interior panels, Insulating foams, Non-food } \\
\text { disposable containers, Concrete and asphalt release } \\
\text { fluids, Floor strippers, Wood and concrete sealers, } \\
\text { Household insulation, Decorative composites, Mold } \\
\text { and trim, Adhesives, Films }\end{array}$ \\
\hline Food sector & $\begin{array}{l}\text { Food containers at sporting events, Food containers at } \\
\text { restaurants, Water bottles, Other bioplastic bottles, } \\
\text { Disposable cutlery }\end{array}$ \\
\hline $\begin{array}{l}\text { Pharmaceutic } \\
\text { s and } \\
\text { neutraceutics }\end{array}$ & 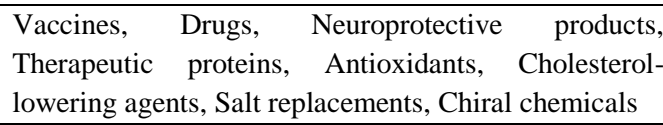 \\
\hline $\begin{array}{l}\text { Specialty } \\
\text { chemicals }\end{array}$ & $\begin{array}{l}\text { Enzymes, Bulking and thickening agents, Flavours and } \\
\text { fragrances, Bioherbicides and biopesticides }\end{array}$ \\
\hline
\end{tabular}

\section{Appendix 2. Techniques for applying RRI dimensions}

\begin{tabular}{|c|c|c|}
\hline \multirow[t]{2}{*}{$\begin{array}{l}\text { Anticipation } \\
\text { dimension }\end{array}$} & Description & $\begin{array}{l}\text { Anticipation is a dimension that aims at } \\
\text { envisioning the future of bio-based products } \\
\text { innovation. } \\
\text { Anticipation plays an important role at the } \\
\text { beginning of bio-based products development } \\
\text { and in indicating the direction to take in order to } \\
\text { achieve better and more desirable results. }\end{array}$ \\
\hline & $\begin{array}{l}\text { Techniques and } \\
\text { approaches }\end{array}$ & $\begin{array}{l}\text { Foresight } \\
\text { Technology assessment } \\
\text { Horizon scanning } \\
\text { Scenario building } \\
\text { Vision assessment } \\
\text { Socio-literacy techniques }\end{array}$ \\
\hline \multirow{3}{*}{$\begin{array}{l}\text { Reflexivity } \\
\text { dimension }\end{array}$} & Description & $\begin{array}{l}\text { Reflexivity is linked to public dialogue, science } \\
\text { and public collaboration, and anticipation. } \\
\text { Reflecting on underlying motivations, potential } \\
\text { impacts, uncertainties, risks, areas of ignorance, } \\
\text { assumptions, questions, and dilemmas. }\end{array}$ \\
\hline & & $\begin{array}{l}\text { Connection between reflexivity and anticipation } \\
\text { allows avoiding the risk of making wrong } \\
\text { predictions, especially in the early stages of bio- } \\
\text { based products development. }\end{array}$ \\
\hline & $\begin{array}{l}\text { Techniques and } \\
\text { approaches }\end{array}$ & $\begin{array}{l}\text { Multidisciplinary collaboration and training } \\
\text { Embedded social scientists and ethicists in } \\
\text { laboratories } \\
\text { Dialogues } \\
\text { Ethical technology assessment } \\
\text { Codes of conduct } \\
\text { Moratoriums }\end{array}$ \\
\hline \multirow[b]{2}{*}{$\begin{array}{l}\text { Inclusion } \\
\text { dimension }\end{array}$} & Description & $\begin{array}{l}\text { Processes of engagement and dialogue with } \\
\text { different stakeholders in the early stages of bio- } \\
\text { based product innovation. } \\
\text { This enables the introduction of a wide range of } \\
\text { perspectives to reframe issues and the early } \\
\text { warning for areas of potential conflict. }\end{array}$ \\
\hline & $\begin{array}{l}\text { Techniques and } \\
\text { approaches }\end{array}$ & $\begin{array}{l}\text { Consensus conferences } \\
\text { Consulting exercises } \\
\text { Citizens' juries and panels } \\
\text { Focus groups } \\
\text { Public discussions and debate } \\
\text { Science shops } \\
\text { Questionnaires } \\
\text { Deliberate polling } \\
\text { Lay membership of expert bodies } \\
\text { Outreaches } \\
\text { Networks and clusters } \\
\text { User-centered design } \\
\text { Open innovation }\end{array}$ \\
\hline \multirow{4}{*}{$\begin{array}{l}\text { Responsiveness } \\
\text { dimension }\end{array}$} & & $\begin{array}{l}\text { Responsiveness is linked to risk, which is the } \\
\text { probability of an occurrence of an event } \\
\text { multiplied by the amount of the cost of that event, } \\
\text { which bio-based products may bring about. }\end{array}$ \\
\hline & Description & $\begin{array}{l}\text { The risks associated with bio-based products can } \\
\text { be medium or long term, economic, } \\
\text { environmental, security or societal. In this case, } \\
\text { identification and analysis of risks as part of } \\
\text { responsiveness is linked to the anticipation } \\
\text { dimension. }\end{array}$ \\
\hline & & $\begin{array}{l}\text { Discussions involving responsiveness were also } \\
\text { primarily linked to ethics, risks, transparency and } \\
\text { accessibility. }\end{array}$ \\
\hline & $\begin{array}{l}\text { Techniques and } \\
\text { approaches }\end{array}$ & $\begin{array}{l}\text { Constitution of grand challenges and thematic } \\
\text { research programmes } \\
\text { Regulation } \\
\text { Standards } \\
\text { Open access and other mechanisms of } \\
\text { transparency } \\
\text { Niche management } \\
\text { Value-sensitive design } \\
\text { Moratoriums } \\
\text { Stage-gates } \\
\text { Alternative intellectual property regimes }\end{array}$ \\
\hline \multirow{2}{*}{$\begin{array}{l}\text { Sustainability } \\
\text { dimension }\end{array}$} & Description & $\begin{array}{l}\text { Sustainability is identified as a key driver of bio- } \\
\text { based product development. } \\
\text { Identification of the environmental aspects of } \\
\text { business operations. Smart use of natural } \\
\text { resources and investment in eco-efficient } \\
\text { production processes. }\end{array}$ \\
\hline & $\begin{array}{l}\text { Techniques and } \\
\text { approaches }\end{array}$ & $\begin{array}{l}\text { Multiple criteria decision making } \\
\text { Legal framework - Policies and regulations } \\
\text { Standards and certification schemes } \\
\text { Voluntary industry agreements and initiatives } \\
\text { Life-cycle impact assessment } \\
\text { ISO Standards } \\
\text { Eco-efficiency analysis } \\
\text { Profits (Products fit to Sustainability) } \\
\text { PPOSA-Product Sustainability Assessment }\end{array}$ \\
\hline \multirow[t]{2}{*}{$\begin{array}{l}\text { Economic } \\
\text { dimension }\end{array}$} & Description & $\begin{array}{l}\text { Concerns about the impact of bio-based products } \\
\text { on economy and society explain growing calls for } \\
\text { the responsible innovation concept, the } \\
\text { sustainable transition of social and technical } \\
\text { arrangements, and stronger engagement } \\
\text { between science-driven innovation and society. } \\
\text { Bio-based products are not developed only for } \\
\text { the creation process but must comply with the } \\
\text { requirements of meeting needs in terms of value } \\
\text { creation for the scientists, company, the public } \\
\text { and other stakeholders in the process of } \\
\text { economic development. }\end{array}$ \\
\hline & $\begin{array}{l}\text { Techniques and } \\
\text { approaches }\end{array}$ & $\begin{array}{l}\text { Green public procurement } \\
\text { Socio economic impact analysis } \\
\text { Life cycle costing } \\
\text { SWOT analysis } \\
\text { PESTEL analysis } \\
\text { Critical success factors, CSFs } \\
\text { Income economic multipliers }\end{array}$ \\
\hline
\end{tabular}

